\title{
Organogenesis of the digestive system in Neotropical carnivorous freshwater catfish Hemisorubim platyrhynchos (Siluriformes: Pimelodidae) 光
}

\author{
Claudemir Kuhn Faccioli ${ }^{\mathrm{a}, \mathrm{b}}$, Renata Alari Chedid ${ }^{\mathrm{a}}$, Ricardo Hideo Mori ${ }^{\mathrm{a}}$, Antonio Carlos do Amaral ${ }^{\mathrm{a}}$, \\ René Alberto Fuster Belmont ${ }^{\mathrm{c}}$, Irene Bastos Franceschini Vicentini ${ }^{\mathrm{a}}$, Carlos Alberto Vicentini ${ }^{\mathrm{a}, *}$ \\ a Department of Biological Sciences, Faculty of Sciences and Aquaculture Center, São Paulo State University-UNESP, Bauru, SP, Brazil \\ ${ }^{\mathrm{b}}$ Institute of Biosciences, Letters and Exact Sciences, São Paulo State University-UNESP, São José do Rio Preto, SP, Brazil \\ c Hydrobiology and Aquaculture Station of Sao Paulo Energetic Company-CESP, Jupiá, SP, Brazil
}

\section{A R T I C L E I N F O}

Article history:

Received 12 March 2015

Received in revised form 3 September 2015

Accepted 7 September 2015

Available online 11 September 2015

\section{Keywords:}

Neotropical region

Morphology

Larvae

Carnivorous freshwater fish

\begin{abstract}
A B S T R A C T
The morphological development of the digestive system of Hemisorubim platyrhynchos was studied from the day of hatching until 21 days post-hatching (DPH) using histology, histochemistry and scanning electron microscopy to augment the available knowledge regarding the organogenesis of the digestive system of this carnivorous Neotropical fish. The development of the digestive system was divided into four major stages. Stage I (endotrophic period) starts with hatching and ends with the mouth opening at $2 \mathrm{DPH}$. The digestive tract originated as a straight undifferentiated tube and ended as an esophagus with goblet cells, an incipient stomach and an intestine divided into the anterior, middle, posterior and rectum. Stage II (endo-exotrophic period) is from the onset of feeding to exhaustion of the yolk at 4 DPH. Stage III is the period in which the larvae rely exclusively on exogenous feeding but still have no functional stomach. Stage IV is an exotrophic period marked by the appearance of gastric glands at $15 \mathrm{DPH}$. At $20 \mathrm{DPH}$, the saccular stomach can be observed. Fish growth was largely variable over the time period studied, and the variability was predominant between the period in which the yolk was present and after its exhaustion. The mixed feeding period is short, and the larvae subsequently survive solely by exogenous feeding without a functional stomach for 15 days. During this period, the primary site of digestion is the anterior intestine, which presents with a saccular shape. The accessory glands, liver and pancreas were differentiated at $2 \mathrm{DPH}$ and thus contributed to extracellular digestion. Also observed in the intestine were supranuclear inclusions that could promote intracellular digestion. The rectal columnar epithelium showed scarce goblet cells but had apical mucosubstances that were involved in fecal transit, epithelial protection and in the final absorption of substances. Gastric glands appeared at $15 \mathrm{DPH}$ and, until this period, the larvae should receive live feed and after 15 DPH may be weaned. H. platyrhynchos farmers should also be alert to differences in the size of the fish because this species presents cannibalism and needs to be separated into homogeneous batches.
\end{abstract}

C 2015 Elsevier B.V. All rights reserved.

\section{Introduction}

Ontogenetic studies during the early stages of fish development, primarily organogenesis of the digestive system, are valuable tools for

\footnotetext{
is Statement of relevance. This study contributes to the knowledge of the digestive tract to improve carnivorous freshwater fish rearing. Sensory structures of Hemisorubim platyrhynchos larvae appeared at $2 \mathrm{DPH}$. H. platyrhynchos has an esophagus with goblet cells and a saccular intestine at the onset of exogenous feeding. Larvae depend exclusively on exogenous feeding at $5 \mathrm{DPH}$, but gastric glands appeared at $15 \mathrm{DPH}$ and, then, larvae could be weaned.

* Corresponding author at: Faculty of Sciences, Department of Biological Sciences, UNESP, Av. Luiz Edmundo Carrijo Coube 14-01, CEP: 17.033-360, Bauru, SP, Brazil. Tel.: + 5514 31036078; fax: +551431036092.

E-mail address: carlosav@fc.unesp.br (C.A. Vicentini).
}

better understanding of larval nutritional physiology and establishing rearing protocols. According to Rønnestad et al. (2013), integrated understanding of the various factors and events that interact during food acquisition and digestion is necessary for designing diets that meet the requirements for optimal ingestion, digestion and absorption. In this case, the health and quality of spawners and environmental conditions during egg incubation determine the amount and quality of endogenous reserves (yolk) of larvae, and environmental and feeding conditions affect the rate of larval development (Hachero-Cruzado et al., 2009). Fish larvae need their feeding and digestive systems to develop quickly. Once the endogenous reserves are depleted, they need to begin capturing, ingesting and digesting food to provide fuel for the intense processes of metabolism and growth (Cuenca-Soria et al., 2013). The basic mechanisms of organ and system development 
are similar in all teleosts, even though there are considerable interspecies differences regarding the relative timing of differentiation, development and functionality during early ontogeny (Treviño et al., 2011). According to Rønnestad et al. (2013), the variety in ontogeny, feeding physiology and behavior even within the same family should be taken into account. Thus, species-specific findings for a process or function in a model species cannot be extrapolated directly to other teleosts, and specific validation studies are essential. Several studies have analyzed the development of the digestive system in fish, including in Channos chanos (Ferraris et al., 1987), Sparus aurata (Sarasquete et al., 1995), Pleuronectes ferruginea (Baglole et al., 1997), Mugil platunus (Galvão et al., 1997), Paralichthys californicus (Gisbert et al., 2004), Pangasius sutchi (Islam, 2005), Seriola lalandi (Chen et al., 2006), Clarias gariepinus (Osman et al., 2008), Rhamdia quelen (Amorim et al., 2009), Scophthalmus rhombus (Hachero-Cruzado et al., 2009), Ompok bimaculatus (Pradhan et al., 2012), Trachinotus ovatus (Ma et al., 2014) and Thunnus thynnus (Yúfera et al., 2014). Although there are many larvae studies, knowledge of the ontogeny of the digestive system of Neotropical fish is limited to a few species (Portella et al., 2014). Thus, understanding the functions and limitations in processing capacity of the digestive system during the early stages of life continues to be a key to the success of larviculture, with the timing of organ development and how it relates to digestion critical to the generation of better rearing systems (Rønnestad et al., 2013).

Hemisorubim platyrhynchos belongs to the family Pimelodidae and the order Siluriformes. This is a migratory species without parental care that is widely distributed in the Neotropical region, with reports indicating its presence in the Orinoco, Amazon, Paraguay, Uruguay and Paraná River basins. According to Bressan et al. (2009), $H$. platyrhynchos is a nocturnal carnivorous fish, and the population size of this species has been reduced because of habitat destruction primarily as a consequence of the construction of hydroelectric dams that interrupt the flow of migration required for reproduction. This species is valuable for aquaculture because of the quality and flavor of its meat and its absence of intramuscular bones. Thus, the aim of this study was to describe the organogenesis of the digestive system of H. platyrhynchos from hatching to 21 days of life for a better understanding of morphofunctional aspects of digestion in Neotropical carnivorous fish larvae. This study will be useful in guiding feed management protocols and farming techniques to increase the production and efficiency of larviculture.

\section{Materials and methods}

\subsection{Rearing conditions, sampling and growth measurements}

H. platyrhynchos gametes were obtained by induced spawning in the Hydrobiology and Aquaculture Station of São Paulo Energetic Company (CESP), Jupiá, SP, Brazil. Fertilized eggs (85\% fertilization rate) were incubated at $29.2 \pm 1.0^{\circ} \mathrm{C}$, and hatching occurred at $15-17$ h postfertilization (95\% hatching rate). During the period studied, the levels of dissolved oxygen $(7.3 \pm 0.5 \mathrm{mg} / \mathrm{l}), \mathrm{pH}(8.2 \pm 0.5)$ and ammonia $(12.5 \pm 1.0 \mu \mathrm{g} / \mathrm{l})$ were controlled. Larvae were fed Artemia sp. since 3 $\mathrm{DPH}$. Specimens were collected ( $n=15)$ at 4 -h intervals from hatching to 5 days post-hatching (DPH) and at one-day intervals thereafter until $21 \mathrm{DPH}$. For sampling, the specimens were euthanized (overdose of benzocaine) and fixed for $24 \mathrm{~h}$ at $4{ }^{\circ} \mathrm{C}$ in a solution of $4 \%$ paraformaldehyde and $2.5 \%$ glutaraldehyde in phosphate buffer ( $\mathrm{pH} 7.4$ ). After fixation, the samples were analyzed, measured for the standard length (SL) (i.e., from the jaw to the end of the notochord) and documented using an M50 stereomicroscope (Leica, Germany). The animals were measured and the growth was determined by the absolute growth rate (AGR) as $\mathrm{mm}$ /day and specific growth rate (SGR) as \%/day (Hopkins, 1992). AGR was calculated by $\mathrm{AGR}=\left(\mathrm{SL}_{\mathrm{f}}-\mathrm{SL}_{\mathrm{i}}\right) / \Delta t$, and SGR was determined by SGR $=100 *\left(\operatorname{LnSL}_{\mathrm{f}}-\mathrm{LnSL}_{\mathrm{i}}\right) / \Delta t$, where $\mathrm{SL}_{\mathrm{f}}$ and
$\mathrm{SL}_{\mathrm{i}}$ are the final and initial standard length $(\mathrm{mm})$ of the fish, respectively, and $\Delta t$ is the time interval (days) between sampling (Hopkins, 1992).

\subsection{Histological and histochemical analysis procedures}

Specimens were dehydrated in graded ethanol solutions and embedded in paraplast (Oxford, USA) or methacrylate resin (Leica, Germany). Sagittal or transverse sections of paraplast (3-7 $\mu \mathrm{m}$ thick) or methacrylate resin (2-3 $\mu \mathrm{m}$ thick) were submitted for staining with hematoxylin-eosin (HE) and 1\% toluidine blue (TB). For histochemical tests, periodic acid-Schiff (PAS) was used to stain neutral mucins, and alcian blue $(A B) \mathrm{pH} 1.0$ and 2.5 was used to stain acidic mucins (Suvarna et al., 2013). Sections were analyzed and photo-documented using a BX50 microscope (Olympus, Japan).

\subsection{Ultrastructural analysis procedures using a scanning electron microscope}

After fixation, the samples were post-fixed for $2 \mathrm{~h}$ in $1 \%$ osmium tetroxide ( $\mathrm{pH} 7.4)$ and dehydrated in a graded ethanol solutions. These fragments were processed to obtain the critical point (EMS 850, Electron Microscopy Sciences, USA) and sputtered with colloidal gold (Vacuum Desk II, Denton Vacuum, USA). Analysis and photographic documentation were performed using a Quanta 200 scanning electron microscope (Fei, USA) at the Electron Microscopy Center of the Institute of Biosciences of Botucatu, UNESP, Brazil.

\subsection{Ethical note}

This study was approved by the Ethical Committee for Research of the Faculty of Sciences at São Paulo State University-UNESP, Bauru, SP, Brazil, under protocol no. 565/46/01/10.

\section{Results}

\subsection{Growth and initial development}

At hatching, $H$. platyrhynchos presented a mean standard length (SL) of $3.23 \pm 0.10 \mathrm{~mm}$ and increased to $7.90 \pm 0.68 \mathrm{~mm}$ at $21 \mathrm{DPH}$ (Fig. 1). The absolute growth rate (AGR) during the period studied was 0.22 $\mathrm{mm} / \mathrm{day}$, and the specific growth rate (SGR) was $4.26 \% /$ day. However, from hatching to $5 \mathrm{DPH}$ (with yolk), the AGR was $0.60 \mathrm{~mm} /$ day, and the SGR was $13.80 \% /$ day. From 5 to 21 DPH (yolk exhausted), the AGR was 0.13 , and the SGR was $2.01 \%$ day. The ontogenetic development of $H$. platyrhynchos was divided into four major stages. Stage I (endotrophic period) starts with hatching (SL $3.23 \pm 0.10 \mathrm{~mm}$ ) and ends with mouth opening at $2 \mathrm{DPH}$ (Fig. $1 \mathrm{~A}$ and $\mathrm{B}$ ). At hatching, the digestive tract is a straight tube; at the end of stage I, the esophagus with goblet cells, the incipient stomach and the intestine, which were divided into anterior, middle, posterior and rectum sections, were observed. Stage II is the endo-exotrophic period from the onset of feeding (3 DPH, SL $4.88 \pm 0.13 \mathrm{~mm}$ ) to exhaustion of the yolk (4 DPH) (Fig. 1C and D). Stage III (5 DPH, SL $5.61 \pm 0.10 \mathrm{~mm}$, to $14 \mathrm{DPH}$ ) is the period in which the larvae rely exclusively on exogenous feeding but still have no functional stomach (Fig. $1 \mathrm{E}$ and F). In this stage, the intestine increased in length and the middle intestine began to loop. Stage IV is an exotrophic period marked by the appearance of gastric glands at 15 DPH (SL $7.44 \pm 0.70 \mathrm{~mm}$ ) (Fig. 1G). At $20 \mathrm{DPH}$, the saccular stomach can be observed (Fig. $1 \mathrm{H}$ and I).

Upon hatching, the larvae were transparent with a yellowish yolk and chromatophores in the anterior and posterior regions of the yolk sac (Fig. 1A). The digestive tract was a straight tube located dorsally to the yolk sac with the end portion bent ventrally (Fig. 1B). A few hours after hatching, the barbels, eyes and nostrils were observed (Fig. 1C and D). During the growth of the fish, the digestive tract increased in length, primarily in the intestine, which expanded the lumen and 

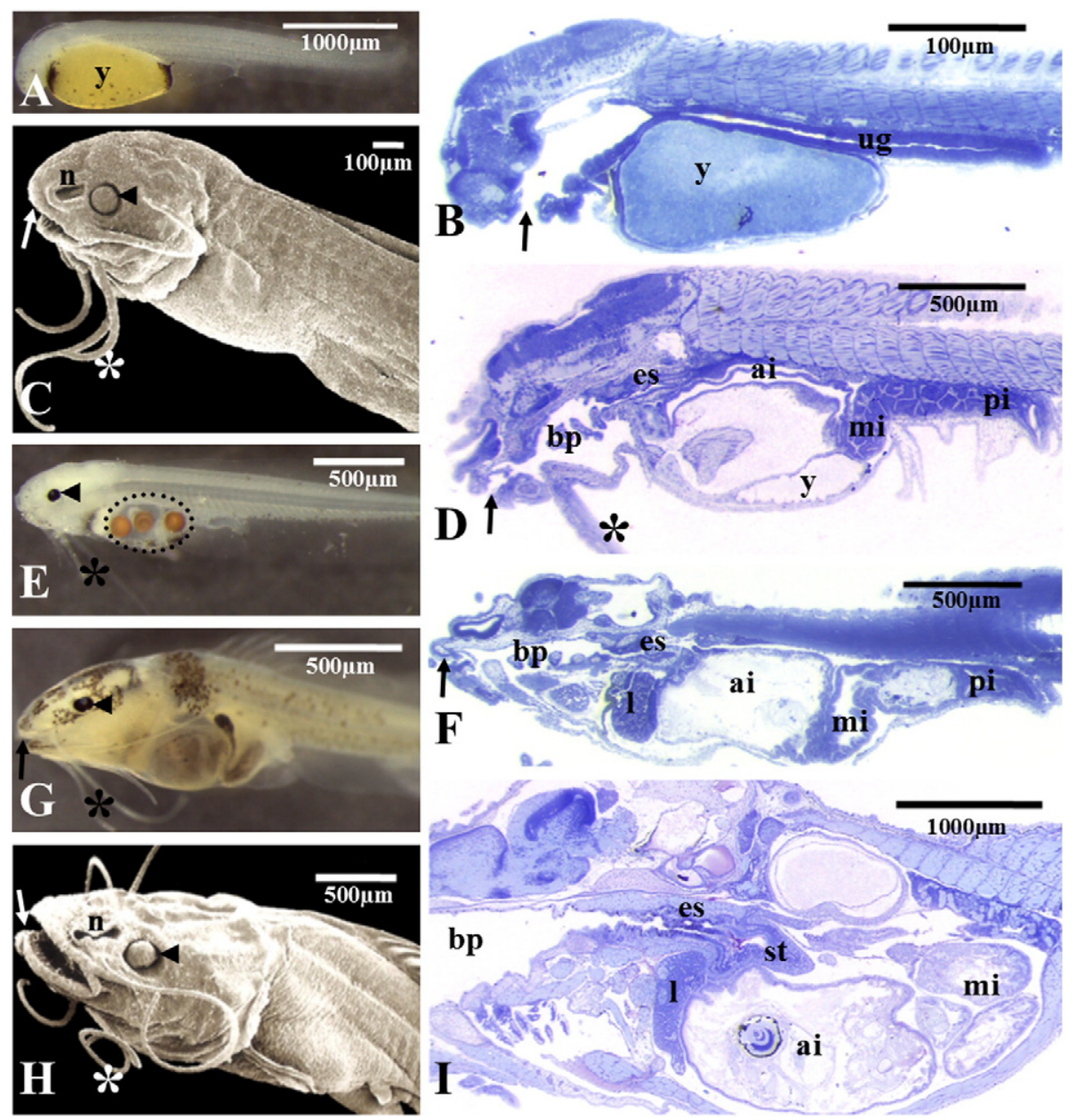

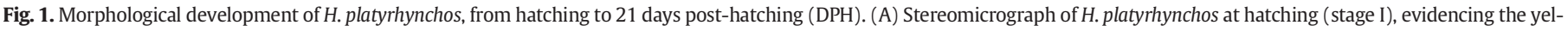

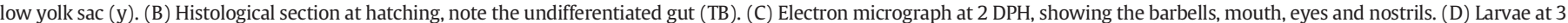

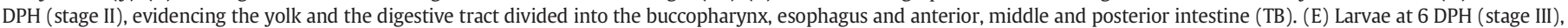

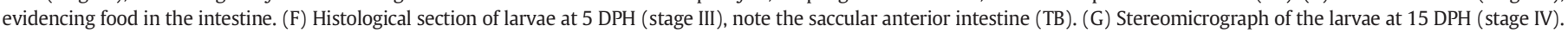

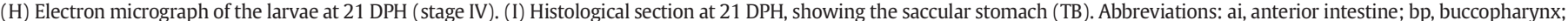
es, esophagus; l, liver; mi, middle intestine; n, nostrils; pi, posterior intestine; st, stomach; ug, undifferentiated gut; y, yolk; arrow, mouth; arrowhead, eyes; asterisk, barbels.

showed a saccular shape (Fig. 1F). At this moment, the larvae already had their mouths open, and they had developed their sensory structures (i.e., barbels, eyes and nostrils). The swim bladder starts to inflate at 2 $\mathrm{DPH}$. At the end of the experimental period, the digestive tract consisted of the buccopharynx, esophagus, stomach (cardiac, fundic and pyloric) and intestine (anterior, middle, posterior and rectum) (Fig. 1H). The pyloric caeca were absent in this specie. During the studied period, $H$. platyrhynchos also presented with cannibalistic behavior, as two small larvae were found in the anterior intestine of a larger larva. The main ontogenetic events observed in this study are summarized in Table 1.

\subsection{Buccopharynx}

At hatching, the buccopharyngeal cavity was present and lined by a simple squamous epithelium surrounded by a thin layer of connective tissue (Fig. 1B). At $2 \mathrm{DPH}$, the mouth opened in a ventral position, and the first teeth were observed, increasing in number with growth of the fish (Fig. 1D). The mouth arrived at the terminal position at $4 \mathrm{DPH}$. The first goblet cells appeared before mouth opening, and they remained scattered even with fish growth (Fig. 2A). Goblet cells showed reactivity with both PAS and AB (Fig. $2 B$ and Table 2 ). Taste buds were also observed in the buccopharyngeal cavity at $3 \mathrm{DPH}$ (Fig. 2A). Using histochemical techniques, the taste buds presented with the strongest
Table 1

Main morphological events in development of $H$. platyrhynchos, from the hatching to 21 $\mathrm{DPH}$

\begin{tabular}{|c|c|c|c|c|}
\hline Stage & DPH & Food source & $\begin{array}{l}\mathrm{SL} \\
(\text { mean } \pm \mathrm{SD})\end{array}$ & Main morphological events \\
\hline I & $0-2$ & Endogenous & $3.23 \pm 0.10$ & $\begin{array}{l}\text { Goblet cells in buccopharynx } \\
\text { and esophagus } \\
\text { Mouth opening } \\
\text { First teeth } \\
\text { Anterior intestine saccular } \\
\text { Liver and pancreas developed } \\
\text { Barbell developed }\end{array}$ \\
\hline II & $3-4$ & Endo-exogenous & $4.88 \pm 0.13$ & $\begin{array}{l}\text { Intestine: anterior, middle, } \\
\text { posterior and rectum } \\
\text { Goblet cells in intestine } \\
\text { Longitudinal folds in esophagus } \\
\text { First taste buds } \\
\text { Mouth in terminal position } \\
\text { Yolk exhausted }\end{array}$ \\
\hline III & $5-14$ & Exogenous & $5.61 \pm 0.10$ & Loops in the middle intestine \\
\hline IV & $15-21$ & Exogenous & $7.44 \pm 0.70$ & $\begin{array}{l}\text { First gastric glands } \\
\text { Saccular stomach } \\
\text { Gastric epithelial cells with } \\
\text { neutral mucins }\end{array}$ \\
\hline
\end{tabular}

$\overline{\text { Days post-hatching (DPH); mean standard length (SL) in first day of stage; standard devi- }}$ ation (SD). 


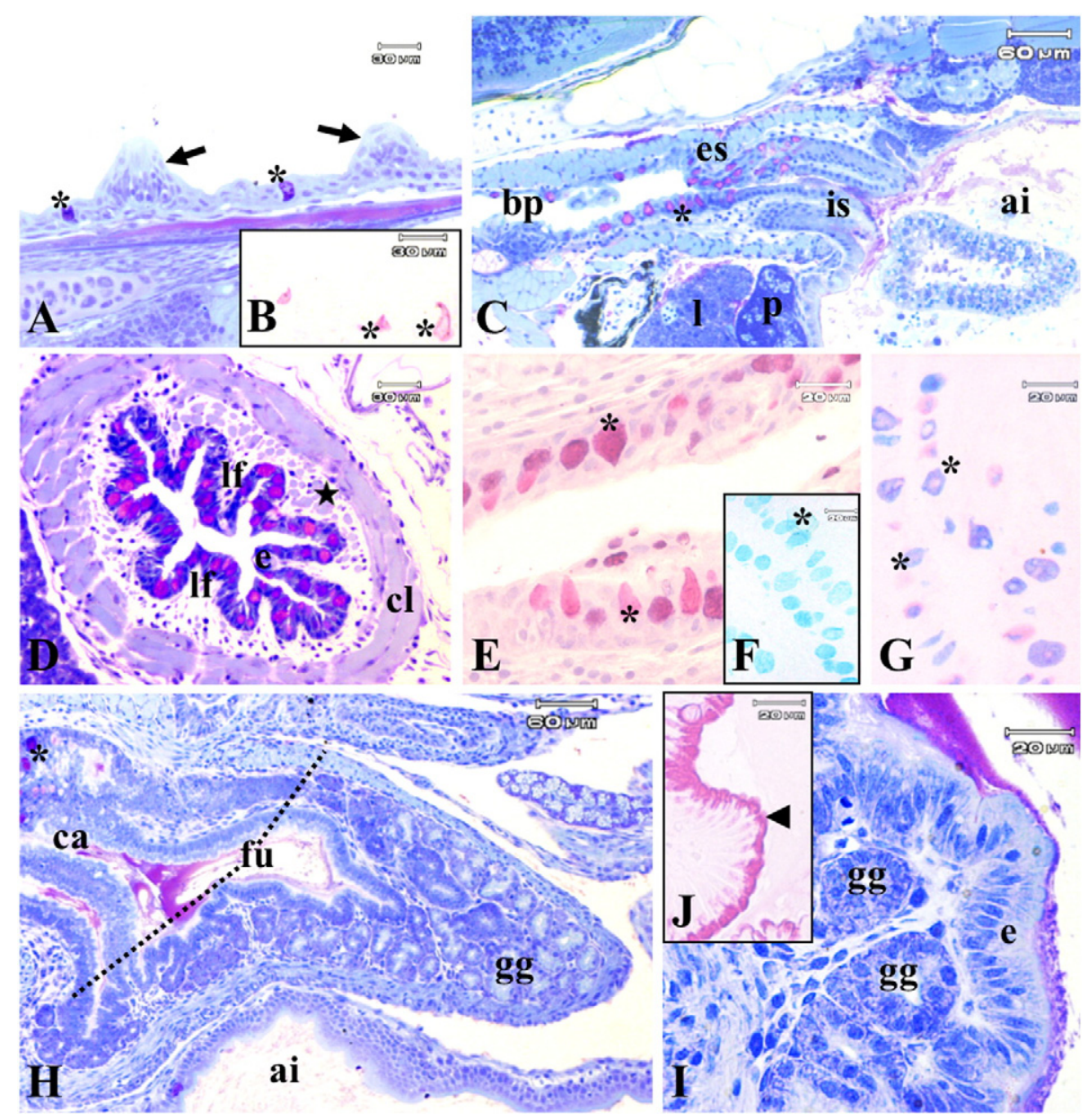

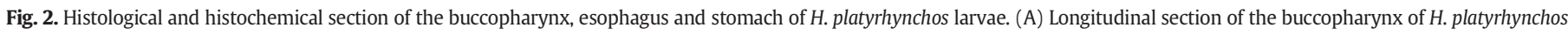

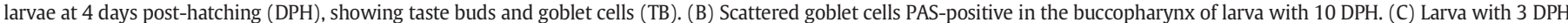

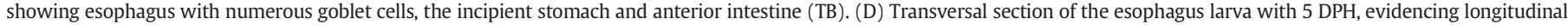

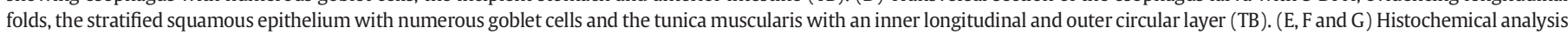

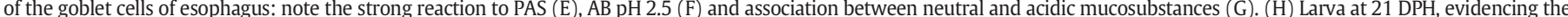

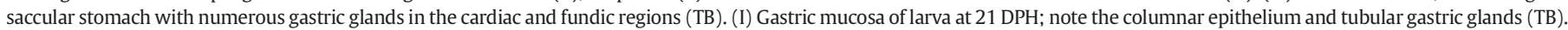

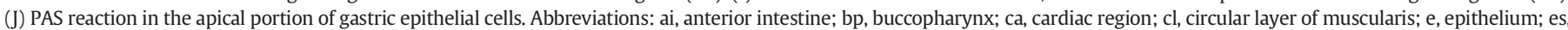

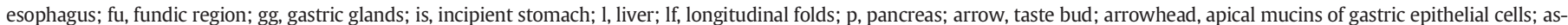
terisk, goblet cells; star, longitudinal layer of muscularis.

reaction to PAS and $\mathrm{AB}$. As the fish grew, the buccopharyngeal cavity epithelium became a stratified squamous epithelium (Fig. 2A).

\subsection{Esophagus}

Before the onset of exogenous feeding, a short and rudimentary esophagus was observed to be lined by a stratified squamous epithelium with scattered goblet cells. As the fish grew, the esophageal mucosa showed longitudinal folds, and the goblet cells increased in number
(Fig. 2C and D). Histochemical analysis revealed that goblet cells were PAS- and AB-positive starting at 2 DPH (Fig. 2E-G; Table 2). The wall of the esophagus became thick, mainly by the tunica muscularis, which was composed of an inner longitudinal and an outer circular striated muscular layer (Fig. 2C and D). The end of the esophagus was marked by an abrupt change in the stratified squamous epithelium with numerous goblet cells to a simple columnar gastric epithelium without goblet cells (Fig. 2C). Taste buds were not observed in the esophagus.

Table 2

Histochemical analysis in the digestive system of H. platyrhynchos larvae at $21 \mathrm{DPH}$ (stage IV).

\begin{tabular}{|c|c|c|c|c|c|c|c|c|}
\hline \multirow[b]{2}{*}{ Techniques employed } & \multicolumn{8}{|l|}{ Regions } \\
\hline & Esophagus & Stomach (epithelium) & Stomach (glands) & Anterior intestine & Middle intestine & Posterior intestine & Rectum & Liver \\
\hline PAS & +++ & +++ & + & +++ & +++ & +++ & +++ & +++ \\
\hline $\mathrm{AB}$ pH 2.5 & +++ & + & - & ++ & ++ & +++ & ++ & - \\
\hline $\mathrm{AB}$ pH 1.0 & +++ & - & - & + & ++ & +++ & ++ & - \\
\hline $\mathrm{AB}(\mathrm{pH} 2.5)+\mathrm{PAS}$ & $\begin{array}{l}++ \\
\text { Goblet cells }\end{array}$ & $\begin{array}{l}\text { Epithelial cells } \\
\text { E }\end{array}$ & $\begin{array}{l}- \\
\text { Oxynticopeptic cells }\end{array}$ & $\begin{array}{l}+ \\
\text { Goblet cells }\end{array}$ & $\begin{array}{l}++ \\
\text { Goblet cells }\end{array}$ & $\begin{array}{l}++ \\
\text { Goblet cells }\end{array}$ & $\begin{array}{l}++ \\
\text { Epithelial cells }\end{array}$ & $\begin{array}{l}\text { - } \\
\text { Hepatocytes }\end{array}$ \\
\hline
\end{tabular}

Staining intensity: $(-)$ negative; $(+)$ weak; $(++)$ moderate; $(+++)$ strong. 


\subsection{Stomach}

The stomach was the last organ in the digestive system to begin differentiation. At $2 \mathrm{DPH}$, the incipient stomach was observed between the esophagus and the saccular anterior intestine (Fig. 2C). The first gastric glands appeared at $15 \mathrm{DPH}$, but the saccular J-shaped stomach was only observed at $20 \mathrm{DPH}$. At this time, the stomach was divided into three regions: the cardiac, fundic and pyloric (Fig. $2 \mathrm{H}$ ). The gastric mucosa was lined by simple columnar epithelium with nuclei in the basal third of the cells (Fig. $2 \mathrm{H}$ and I). The gastric epithelial cells demonstrated apical neutral mucins revealed by the PAS technique (Fig. 2J; Table 2). The gastric glands were numerous in the fundic region, were scarce in the cardiac region and were not observed in the pyloric region. These glands are tubular and surrounded by connective tissue (Fig. $2 \mathrm{H}$ ). The submucosa was thin and constituted of dense connective tissue. The tunica muscularis was subdivided into an inner circular and an outer longitudinal layer. In the pyloric region, the circular layer became thicker to form the pyloric sphincter.

\subsection{Intestine}

At hatching, the straight intestine was lined by a simple columnar epithelium, and the end portion was bent ventrally. As the fish grew, the intestine presented with many folds. At $3 \mathrm{DPH}$, it was constituted by four regions: anterior, middle, posterior and rectal (Fig. 1F). The anterior intestine expanded the lumen, presenting with a saccular shape. The middle intestine possessed loops and a dilated lumen. The posterior region was straight with many longitudinal folds, whereas the rectal region did not have any folds (Fig. 3D). The intestine showed a simple columnar epithelium, but in the anterior intestine, the columnar cells were shorter than in other regions (Fig. 3A-C). Enterocytes showed a basal nucleus and an apical brush border that was PAS positive. At 4 $\mathrm{DPH}$, supranuclear inclusions were also observed in the enterocytes, mainly in the middle and posterior intestine (Fig. 3B). At this time, few goblet cells were present between enterocytes, showing PAS and AB-positive secretory granules (Fig. $3 \mathrm{~F}$ and G; Table 2). As the fish grew, these cells increased in number and were numerous in the posterior intestine but scarce or absent in the rectum (Fig. 3D). In the rectal epithelium, the epithelial cells showed an apical secretion (Fig. 3E) that was reactive by both PAS and $\mathrm{AB}$ (Table 2).

\subsection{Liver and pancreas}

The accessory glands of the digestive system were undifferentiated at hatching, being observed only as a cluster of spherical cells in the ventral region of the digestive tract cranial to the yolk sac. These cells

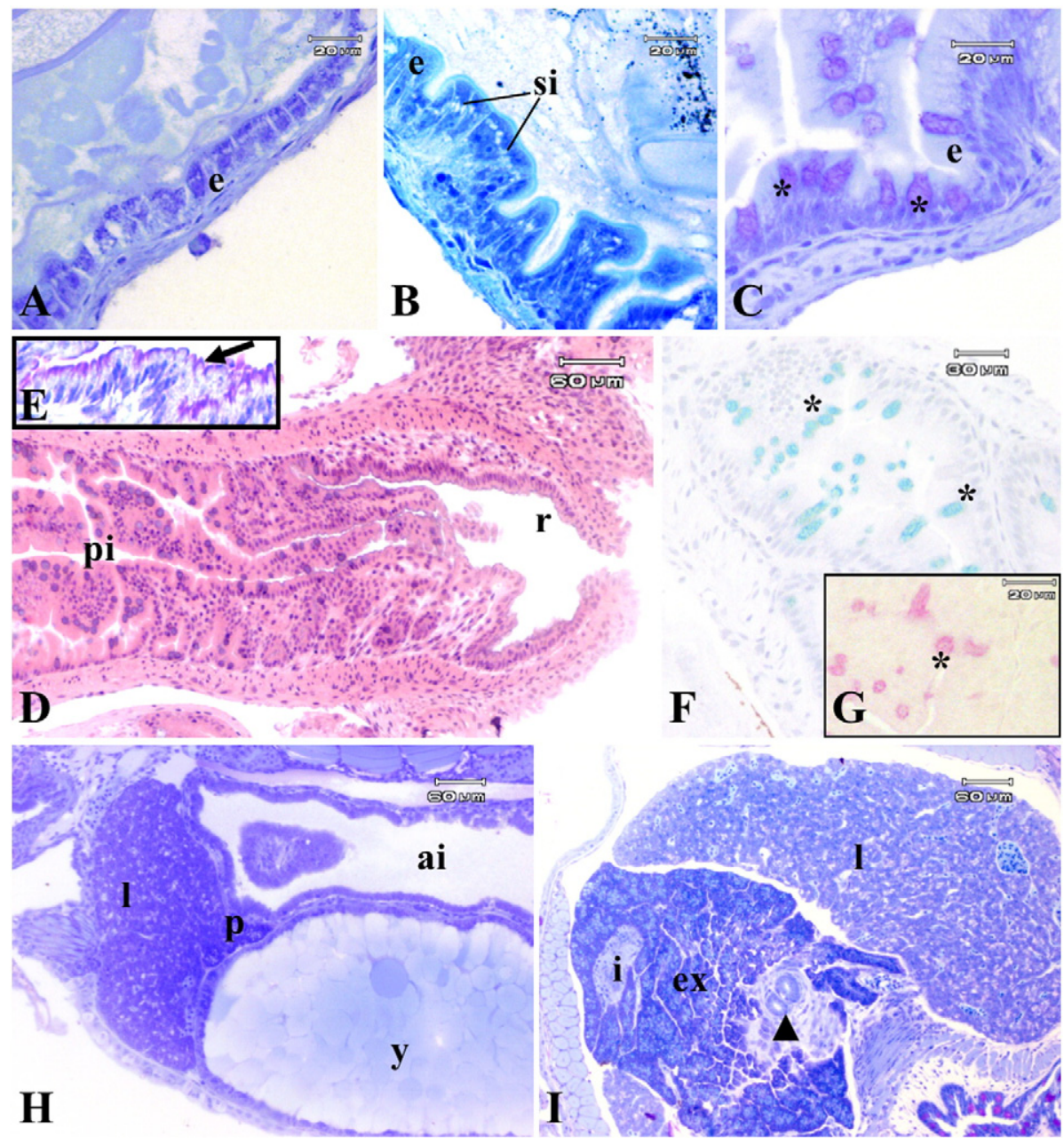

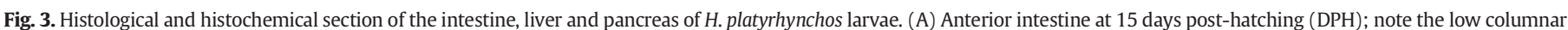

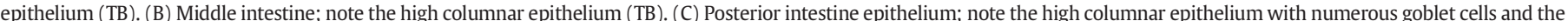

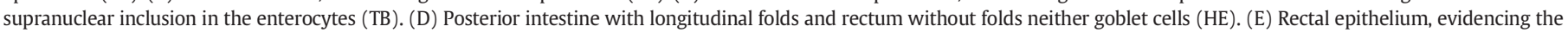

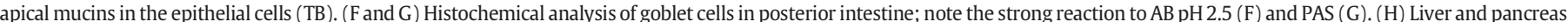

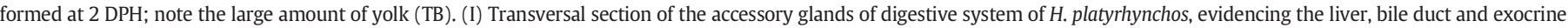

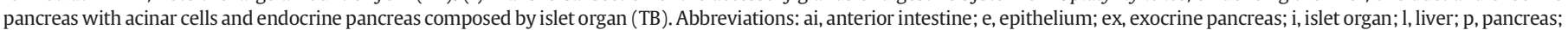
pi, posterior intestine; r, rectum; si, supranuclear inclusion; y, yolk; arrow, apical mucins of epithelial in rectum; asterisk, goblet cell; arrowhead, bile duct. 
increased rapidly in number, and then the liver and pancreas were visualized at $1 \mathrm{DPH}$ (Fig. 3H). Hepatocytes were polyhedral cells with rounded nuclei (Fig. 3I), and the cytoplasm presented with PASpositive glycogen granules (Table 2). The extrahepatic pancreas was observed on the visceral face of the liver (Fig. $3 \mathrm{H}$ and I). This pancreatic tissue was comprised of acinar cells of the exocrine portion and islet cells of the endocrine portion. As the fish grew, the pancreatic tissue began to diffusely distribute around the intestine while also remaining in the visceral face of the liver.

\section{Discussion}

The organogenesis of the digestive system of $H$. platyrhynchos was studied from hatching to 21 days post-hatching. The hatching occurred 15-17 h after fertilization at $29^{\circ} \mathrm{C}$, which is faster than in other catfish (20-23 h for Heterobranchus longifilis at $29^{\circ} \mathrm{C}$ (Nwosu and Holzlöhner, 2000), 24-36 h for Pangasius sutchi at $20{ }^{\circ} \mathrm{C}-30{ }^{\circ} \mathrm{C}$ (Islam, 2005), $25.5 \mathrm{~h}$ for Rhamdia quelen at $26^{\circ} \mathrm{C}$ (Amorim et al., 2009), $40 \mathrm{~h}$ for Clarias gariepinus at $24{ }^{\circ} \mathrm{C}$ (Osman et al., 2008) and $23 \pm 1 \mathrm{~h}$ for Ompok bimaculatus at $27.0 \pm 1.1{ }^{\circ} \mathrm{C}$ (Pradhan et al., 2012)). In this study, development was divided into stage I (endotrophic period), stage II (endo-exotrophic period), stage III (exotrophic period without a functional stomach) and stage IV (exotrophic period with a functional stomach) (Table 1 and Fig. 1). After hatching, this species was transparent, and the digestive tract was a straight, undifferentiated tube. According to Andrade et al. (2014), larvae of H. platyrhynchos were considered altricial. The exclusively endogenous feeding period was short, and at the end of stage I, this species had an open mouth, an esophagus with longitudinal folds and goblet cells, an incipient stomach and the anterior intestine had a saccular shape. At this time, $H$. platyrhynchos also presented with differentiated structures for finding food, including barbels, eyes and nostrils. The barbels of catfish showed a dense number of taste buds, indicating that gustation plays a primary role in orientation and locating food (Iwai, 1980). The small buccopharynx teeth were also present at this stage, which act to trap prey rather than cut, allowing this carnivorous species to swallow the prey whole.

At $3 \mathrm{DPH}$, the mouth of $H$. platyrhynchos was open, and they started exogenous feeding. The time of mouth opening varies among species and is influenced by temperature (Gisbert et al., 2004; Zaiss et al., 2006) because temperature increases metabolism (Qu et al., 2012). Moreover, mouth opening and yolk depletion are generally events that are considered to be markers for the beginning of feeding in fish larvae (Gisbert and Williot, 2002). In this studied species, the yolk was only observed until $4 \mathrm{DPH}$, which is a shorter period than that of other catfish, such as Clarias gariepinus (Osman et al., 2008), Silurus glanis (Kozarić et al., 2008), Rhamdia quelen (Amorim et al., 2009) and Ompok bimaculatus (Pradhan et al., 2012), which all have yolks that last 5 days. In this sense, $H$. platyrhynchos presented a short mixed feeding period (endo-exotrophic) of approximately 2 days. In larval rearing, the onset of feeding and the transition of endogenous to exogenous feeding is a crucial moment in developing fish larvae and they have been associated with massive mortalities (Yúfera and Darias, 2007). According to many authors (Chen et al., 2006; Govoni et al., 1986; Segner et al., 1993), the transition of endo-exogenous to exogenous feeding is a critical period because the fish need to develop the ability to survive on solely exogenous feeding. On the other hand, at the end of the endo-exotrophic period and during stage III, $H$. platyrhynchos still did not have a functional stomach, resulting in slower growth than in the period with endogenous resources (Table 1).

Histological analyses of the buccopharynx of $H$. platyrhynchos revealed scattered taste buds at $3 \mathrm{DPH}$. The taste buds have chemical receptors and mechanoreceptors that increase the efficiency of sorting and selecting food prior to swallowing (Díaz et al., 2009; Northcutt, 2005). The esophagus of $H$. platyrhynchos presented longitudinal folds and an evident tunica muscularis, which enables the distention of the organ and apprehension of prey. The buccopharynx and esophagus had a stratified epithelium with goblet cells that possessed neutral and acidic mucins. According to Galvão et al. (1997), the appearance of goblet cells indicates that the buccopharynx and esophagus are ready to receive exogenous feeding because their secretions protect the epithelium against abrasion and damage caused by the passage of food. Several studies have associated the acidic mucins with the increased viscosity of secretions (Díaz et al., 2008; Tibbetts, 1997) and with lubrication and protection of the epithelium against pathogens and mechanical damage (Fletcher and Grant, 1969; Humbert et al., 1984; Sarasquete et al., 2001). Moreover, neutral mucins are related to the emulsification of food into chyme (Murray et al., 1996) and may indicate pre-gastric digestion (Grau et al., 1992). Thus, the buccopharynx and esophagus of $H$. platyrhynchos contained structures that protected and lubricated the epithelium, indicating that the fish was ready to ingest food at the onset of feeding.

Also at the onset of feeding, the intestine showed a dilated lumen that formed in the anterior region with a saccular shape. This region contained the opening of the duct that secretes bile and pancreatic juice. Many authors have reported larval extracellular proteolytic digestion in the anterior intestine, where the $\mathrm{pH}$ is alkaline and trypsin-like enzymes promote proteolytic activity (Gisbert et al., 2004; Walford and Lam, 1993; Zambonino-Infante and Cahu, 2001). In Pseudosciaena crocea (Ma et al., 2005), Salminus brasiliensis (Vega-Orellana et al., 2006), Atractoscion nobilis (Galaviz et al., 2011) and Huso huso (Asgari et al., 2013), pancreatic enzyme activities, including trypsin and chymotrypsin, were detected at the first days of the larval stage, emphasizing the importance of these alkaline enzymes during nascent development. $H$. platyrhynchos have a developed liver and extrahepatic pancreas at the onset of feeding, as is observed in adult animals (Faccioli et al., 2014b). Thus, prior to stomach development, the anterior intestine is the primary site of extracellular digestion using pancreatic enzymes and bile juices together with intestinal enzymes.

All intestinal regions of the studied species presented a simple columnar epithelium, although the columnar cells in the anterior intestine were shorter than in the middle and posterior intestine due to the saccular shape of the anterior region. Enterocytes showed supranuclear inclusions primarily in the middle and posterior intestine, which has been similarly observed in many teleosts, including Paralichthys californicus (Gisbert et al., 2004), Plectropomus leopardus (Qu et al., 2012) and Thunnus thynnus (Yúfera et al., 2014). According to Govoni et al. (1986), the existence of acidophilic supranuclear inclusions in enterocytes indicates pinocytotic absorption and intracellular protein digestion during larval developmental. In addition, enterocytes of the studied species showed a PAS-positive brush border. The presence of neutral mucins together with alkaline phosphatases in the intestinal brush border has been correlated to the absorption and transport of macromolecules through membranes (Sarasquete et al., 2001; Stroband et al., 1979).

Goblet cells were visualized throughout the intestine, but they were most numerous in the posterior intestine and were scarce or absent in the rectum. This feature was also observed in adult $H$. platyrhynchos (Faccioli et al., 2014a). Histochemical analyses revealed that goblet cells showed a strong reaction to PAS, whereas staining for AB was increased in the posterior intestine (Table 2). Anderson (1986) associated neutral mucins with supply co-factors required for the enzymatic breakdown of food, and Rhodes et al. (1985) related the acidic mucins to increased resistance of mucus to bacterial degradation and to the absorption of proteins or protein fragments, ions and fluids (Petrinec et al., 2005). The epithelial lining of the rectum exhibited apical secretions composed of neutral and acidic mucins that may be involved in fecal transit, epithelial protection and in the final absorption of substances (Carrassón et al., 2006; Murray et al., 1996).

At $15 \mathrm{DPH}$, the first gastric glands were observed in the stomach of $H$. platyrhynchos, marking the beginning of stage IV. Generally, gastric glands in fish are composed of a single cell type, oxynticopeptic cells, which are responsible for the production of hydrochloric acid and 
pepsinogen (Naguib et al., 2011; Ostos-Garrido et al., 1993). According to Yang et al. (2010), gastric glands in Siluriformes fish appear earlier than in other orders. However, in H. platyrhynchos, the gastric glands appeared at $15 \mathrm{DPH}$, which can be considered a long period as it is longer than that of other catfish, including Pelteobagrus fulvidraco at $3 \mathrm{DPH}$ (Yang et al., 2010), Ompok bimaculatus at 8 DPH (Pradhan et al., 2012) and Pangasius sutchi at 9 DPH (Islam, 2005). The appearance of these glands is an important event in larviculture and, together with pepsin secretion, indicates that the stomach has become functional and marks the transition from larvae to juveniles (Baglole et al., 1997; Ma et al., 2014; Segner et al., 1994). According to Silveira et al. (2013), a morphologically functional stomach and the presence of pepsin-like activity observed in Rhamdia quelen $48 \mathrm{~h}$ after hatching indicate that the larvae are capable of ingesting and digesting inert food. In Salminus brasiliensis larvae, Vega-Orellana et al. (2006) reported that inert food resulted in satisfactory growth only when larvae had a functional stomach. The same was observed in Clarias gariepinus and Scophthalmus maximus by Segner et al. (1993), concluding that a functional stomach is necessary for utilizing dry food as efficiently as live food. Thus, only with the development of gastric glands at $15 \mathrm{DPH}$ should $H$. platyrhynchos be weaned onto an inert food.

The histochemical analyses revealed that the gastric epithelium had a strong reaction to PAS in the apical region of the epithelial cells (Table 2). This reaction was observed in the majority of teleosts, and it is primarily caused by neutral mucins that are secreted by exocytosis to the gastric lumen (Noaillac-Depeyre and Gas, 1978). According to Ferraris et al. (1987), neutral mucins may protect the epithelium of the stomach against autodigestion by secretions produced by the gastric glands. Moreover, during larviculture of $H$. platyrhynchos, cannibalism was observed. Folkvord and Otterå (1993) reported that cannibalism by differences in size is a major barrier to the intensive farming of carnivorous species. Thus, the larvae must be separated by size into homogeneous size groups.

In summary, this study presents the rarest data on the organogenesis of the digestive system of $H$. platyrhynchos, which is provided to aid in improving the rearing systems of this carnivorous catfish from the Neotropical region. The changes that occur in the digestive system during the first few days are enough to allow for the ingestion and digestion of food, through the appearance of folds and goblet cells in the esophagus, a saccular anterior intestine and development of the liver and pancreas. Feeding occurs at $3 \mathrm{DPH}$, but gastric glands only appear at $15 \mathrm{DPH}$. During this period, extracellular digestion occurs in the anterior intestine. Thus, weaning of this species should occur only after the gastric glands appear at $15 \mathrm{DPH}$.

\section{Acknowledgments}

This work was supported by grants from Fundação de Amparo à Pesquisa do Estado de São Paulo-FAPESP (08/55573-7), and Conselho Nacional de Desenvolvimento Científico e Tecnológico-CNPq (301696/ 2007-1). The authors are grateful to the Hydrobiology and Aquaculture Station of São Paulo Energetic Company (CESP), Jupiá, SP, Brazil, for providing the specimens.

\section{References}

Amorim, M.P., Campos Gomes, B.V., Martins, Y.S., Sato, Y., Rizzo, E., Bazzoli, N., 2009. Early development of the silver catfish Rhamdia quelen (Quoy and Gaimard, 1824) (Pisces: Heptapteridae) from the São Francisco River Basin, Brazil. Aquac. Res. 40, 172-180.

Anderson, T.A., 1986. Histological and cytological structure of the gastrointestinal tract of the luderick, Girella tricuspidata (Pisces, Kyphosidae), in relation to diet. J. Morphol. 190, 109-119.

Andrade, F.F., Makrakis, M.C., Lima, A.F., Assumpção, L., Makrakis, S., Pini, S.F.R., 2014 Desenvolvimento embrionário, larval e juvenil de Hemisorubim platyrhynchos (Siluriformes, Pimelodidae) da bacia do rio Paraná. Iheringia Sér. Zool. 104, 70-80.

Asgari, R., Rafiee, G., Eagderi, S., Noori, F., Agh, N., Poorbagher, H., Gisbert, E., 2013. Ontogeny of the digestive enzyme activities in hatchery produced Beluga (Huso huso). Aquaculture 416-417, 33-40.
Baglole, C.J., Murray, H.M., Goff, G.P., Weight, G.M., 1997. Ontogeny of the digestive tract during larval development of yellowtail flounder: a light microscopic and mucous histochemical study. J. Fish Biol. 51, 120-134.

Bressan, P.M., Kierulff, M.C.M., Sugieda, A.M., 2009. Fauna ameaçada de extinção no estado de São Paulo: Vertebrados. Fundação Parque Zoológico de São Paulo, Secretaria do Meio Ambiente, São Paulo.

Carrassón, M., Grau, A., Dopazo, L.R., Crespo, S., 2006. A histological, histochemical and ultrastructural study of the digestive tract of Dentex dentex (Pisces, Sparidae). Histol. Histopathol. 21, 579-593.

Chen, B.N., Qin, J.G., Kumar, S.M., Hutchinson, W.G., Clarke, S.M., 2006. Ontogenetic development of digestive enzymes in yellowtail kingfish Seriola lalandi larvae. Aquaculture 260, 264-271.

Cuenca-Soria, C.A., Álvarez-González, C.A., Ortiz-Galindo, J.L., Tovar-Ramírez, D., GuerreroZárate, R., Aguilar-Hernández, S., Perera-García, M.A., Hernández-Gómez, R., Gisbert, E., 2013. Histological development of the digestive system of Mayan cichlid Cichlasoma urophthalmus (Günther 1862). J. Appl. Ichthyol. 29, 1304-1312.

Díaz, A.O., García, A.M., Goldemberg, A.L., 2008. Glycoconjugates in the mucosa of the digestive tract of Cynoscion guatucupa: a histochemical study. Acta Histochem. 110, 76-85.

Díaz, A.O., Castro, M.G., García, A.M., Astarloa, J.M.D., Figueroa, D.E., 2009. Gross morphology and surface ultrastructure of the gills of Odontesthes argentinensis (Actinopterygii, Atherinopsidae) from a Southwestern Atlantic coastal lagoon. Tissue Cell 41, 193-198.

Faccioli, C.K., Chedid, R.A., Amaral, A.C., Franceschini-Vicentini, I.B., Vicentini, C.A., 2014a. Morphology and histochemistry of the digestive tract in carnivorous freshwater Hemisorubim platyrhynchos (Siluriformes: Pimelodidae). Micron 64, 10-19.

Faccioli, C.K., Chedid, R.A., Bombonato, M.T.S., Vicentini, C.A., Franceschini-Vicentini, I.B., 2014b. Morphology and histochemistry of the liver of carnivorous fish Hemisorubim platyrhynchos. Int. J. Morphol. 32, 715-720.

Ferraris, R.P., Tan, J.D., De la Cruz, M.C., 1987. Development of the digestive tract of milkfish, Chano chanos (Forsskal): histology and histochemestry. Aquaculture 61, 241-257.

Fletcher, T.C., Grant, P.T., 1969. Immunoglobulins in the serum and mucus of the plaice (Pleuronectes platessa). Biochem. J. 115, 65.

Folkvord, A., Otterå, H., 1993. Effects of initial size distribution, day length, and feeding frequency on growth, survival and cannibalism in juvenile Atlantic cod (Gadus morhua L.). Aquaculture 114, 243-260.

Galaviz, M.A., García-Gasca, A., Drawbridge, M., Álvarez-González, C.A., López, L.M., 2011. Ontogeny of the digestive tract and enzymatic activity in white seabass, Atractoscion nobilis, larvae. Aquaculture 318, 162-168.

Galvão, M.N.S., Fenerich-Verani, N., Yamanaka, N., Oliveira, I.R., 1997. Histologia do sistema digestivo da tainha Mugil platunus Gunther, 1880 (Osteithes, Mugilidae) durante as fases larval e juvenil. Bol. Inst. Pesca 24, 91-100.

Gisbert, E., Williot, P., 2002. Advances in the larval rearing of Siberian sturgeon. J. Fish Biol. 60, 1071-1092.

Gisbert, E., Piedrahita, R.H., Conklin, D.E., 2004. Ontogenetic development of the digestive system in California halibut (Paralichthys californicus) with notes on feeding practices. Aquaculture 232, 455-470.

Govoni, J.J., Boehlert, G.W., Watanabe, Y., 1986. The physiology of digestion in fish larvae. Environ. Biol. Fish. 16, 59-77.

Grau, A., Crespo, S., Sarasquete, M.C., Gonzales de Canales, M.L., 1992. The digestive tract of the amberjack Seriola dumerili Risso: a light and scanning electron microscope study. J. Fish Biol. 41, 287-303.

Hachero-Cruzado, I., Ortiz-Delgado, J.B., Borrega, B., Herrera, M., Navas, J.I., Sarasquete, C., 2009. Larval organogenesis of flatfish brill Scophthalmus rhombus L: histological and histochemical aspects. Aquaculture 286, 138-149.

Hopkins, K.D., 1992. Reporting fish growth: a review of the basics. J. World Aquac. Soc. 23, 173-179.

Humbert, W., Kirsch, R., Meister, M.F., 1984. Scanning electron microscopic study of the oesophageal mucous layer in the eel Anguilla anguilla L. J. Fish Biol. 25, 117-122.

Islam, A., 2005. Embryonic and larval development of Thai pangas (Pangasius sutchi Fowler, 1937). Dev. Growth Differ. 47, 1-6.

Iwai, T., 1980. Sensory anatomy and feeding of fish larvae. In: Bardach, J.E., Magnuson, J.J., May, R.C., Reinhart, J.M. (Eds.), Fish Behavior and Its Use in the Capture and Culture of Fishes. ICLARM Conference Proceedings 5, Manila, pp. 124-145.

Kozarić, Z., Kužir, S., Petrinec, Z., Gjurčević, E., Božić, M., 2008. The development of the digestive tract in larval European catfish (Silurus glanis L.). Anat. Histol. Embryol. 37, 141-146.

Ma, H., Cahu, C., Zambonino, J., Yu, H., Duana, Q., Le Gall, M., Mai, K., 2005. Activities of selected digestive enzymes during larval development of large yellow croaker (Pseudosciaena crocea). Aquaculture 245, 239-248.

Ma, Z., Huayang Guo, H., Zheng, P., Wang, L., Jiang, S., Qin, J.G., Zhang, D., 2014. Ontogenetic development of digestive functionality in golden pompano Trachinotus ovatus (Linnaeus 1758). Fish Physiol. Biochem. 40, 1157-1167.

Murray, H.M., Wright, G.M., Goff, G.P., 1996. A comparative histological and histochemical study of the post-gastric alimentary canal from three species of Pleuronectid, the Atlantic halibut, the yellowtail flounder and the winter flounder. J. Fish Biol. 48, 187-206.

Naguib, S.A.A., Ei-Shabaka, H.A., Ashour, F., 2011. Comparative histological and ultrastructural studies on the stomach of Schilbe mystus and the intestinal swelling of Labeo niloticus. Vet. Arh. 7, 251-263.

Noaillac-Depeyre, J., Gas, N., 1978. Ultrastructural and cytochemical study of the gastric epithelium in a fresh water teleostean fish Perea fluviatilis. Tissue Cell 10, 23-37.

Northcutt, R.G., 2005. Taste bud development in the channel catfish. J. Comp. Neurol. 482, $1-16$. 
Nwosu, F.M., Holzlöhner, S., 2000. Influence of temperature on egg hatching, growth and survival of larvae of Heterobranchus longifilis Val. 1840 (Teleostei: Clariidae). J. Appl. Ichthyol. 16, 20-23.

Osman, A.G.M., Wuertz, S., Mekkawy, I.A., Verreth, J., Kirschbaum, F., 2008. Early development of the African catfish Clarias gariepinus (Burchell, 1822), focusing on the ontogeny of selected organs. J. Appl. Ichthyol. 24, 187-195.

Ostos-Garrido, M.V., Gonzalez-Oller, C., Abaurrea Equisoain, M.A., 1993. Histological, histochemical and ultrastructural analysis of the gastric mucosa in Oncorhynchus mykiss. Aquaculture 115, 121-132.

Petrinec, Z., Nejedli, S., Kuzir, S., Opacak, A., 2005. Mucosubstances of the digestive tract mucosa in northern pike (Esox lucius L.) and european catfish (Silurus glanis L.). Vet. Arh. 75, 317-327.

Portella, M.C., Jomori, R.K., Leitão, N.J., Menossi, O.C.C., Freitas, T.M., Kojima, J.T., Lopes, T.S., Clavijo-Ayala, J.A., Carneiro, D.J., 2014. Larval development of indigenous South American freshwater fish species, with particular reference to pacu (Piaractus mesopotamicus): A review. Aquaculture 432, 402-417.

Pradhan, P.K., Jena, J.K., Mitra, G., Sood, N., Gisbert, E., 2012. Ontogeny of the digestive tract in butter catfish Ompok bimaculatus (Bloch) larvae. Fish Physiol. Biochem. 38, 1601-1617.

Qu, M., Ding, S., Xu, X., Shen, M., You, Y., Su, Y., 2012. Ontogenetic development of the digestive system and growth in coral trout (Plectropomus leopardus). Aquaculture 334-337, 132-141.

Rhodes, J.M., Black, R.R., Gallimore, R., Savage, A., 1985. Histochemical demonstration of desialitation and desulphation of normal and inflammatory bowel disease rectal mucus by faecal extracts. Gut 26, 1312-1318.

Rønnestad, I., Yúfera, M., Ueberschär, B., Ribeiro, L., Sæle, Ø., Boglione, C., 2013. Feeding behaviour and digestive physiology in larval fish: current knowledge, and gaps and bottlenecks in research. Rev. Aquac. 5, 59-98.

Sarasquete, C., Polo, A., Yúfera, M., 1995. Histological and histochemical study during larval development of Sparus aurata L. Aquaculture 130, 79-92.

Sarasquete, C., Gisbert, E., Ribeiro, L., Vieira, L., Dinis, M.T., 2001. Glyconjugates in epidermal, branchial and digestive mucous cells and gastric glands of gilthead sea bream, Sparus aurata, Senegal sole, Solea senegalensis and Siberian sturgeon, Acipenser baeri development. Eur. J. Histochem. 45, 267-278.

Segner, H., Roesch, R., Verreth, J., Witt, U., 1993. Larval nutritional physiology: studies with Clarias gariepinus, Coregonus lavaretus and Scophthalmus maximus. J. World Aquac. Soc. 24, 121-134.
Segner, H., Storch, V., Reinecke, M., Kloas, W., Hanke, W., 1994. The development of functional digestive and metabolic organs in turbot, Scophthalmus maximus. Mar. Biol. $119,471-486$

Silveira, J., Silva, C.P., Cargnin-Ferreira, E., Alexandre, D., Elias, M.A., Fracalossi, D.M., 2013. Freshwater catfish jundiá (Rhamdia quelen) larvae are prepared to digest inert feed at the exogenous feeding onset: physiological and histological assessments. Fish Physiol. Biochem. 39, 1581-1590.

Stroband, H.W. Meer H.V.D Timmermans, L.M.M, 1979. Regional functional differentiation in the gut of the grass carp Ctenopharyngodon idella. Histochem. J. 64, 235-249.

Suvarna, S.K., Layton, C., Bancroft, J.D., 2013. Bancroft's Theory and Practice of Histological Techniques. seventh ed. Churchill Livingstone, London.

Tibbetts, I.R., 1997. The distribution and function of mucous cells and their secretions in the alimentary tract of Arrhamphus sclerolepis krefftii. J. Fish Biol. 50, 809-820.

Treviño, L., Álvarez-González, C.A., Perales-García, N., Arévalo-Galán, L., UscangaMartínez, A., Márquez-Couturier, G., Fernández, I., Gisbert, E., 2011. A histologica study of the organogenesis of the digestive system in bay snook Petenia splendida Günther (1862), from hatching to the juvenile stage. J. Appl. Ichthyol. 27, 73-82.

Vega-Orellana, O.M., Fracalossi, D.M., Sugai, J.K., 2006. Dourado (Salminus brasiliensis) larviculture: weaning and ontogenetic development of digestive proteinases. Aquaculture 252, 484-493.

Walford, J., Lam, T.J., 1993. Development of digestive tract and proteolytic enzyme activity in seabass (Lutes calcarifer) larvae and juveniles. Aquaculture 109, 187-205.

Yang, R., Xie, C., Fan, Q., Gao, C., Fang, L., 2010. Ontogeny of the digestive tract in yellow catfish Pelteobagrus fulvidraco larvae. Aquaculture 302, 112-123.

Yúfera, M., Darias, M.J., 2007. The onset of exogenous feeding in marine fish larvae. Aquaculture 268, 53-63.

Yúfera, M., Ortiz-Delgado, J.B., Hoffman, T., Siguero, I., Urup, B., Sarasquete, C., 2014 Organogenesis of digestive system, visual system and other structures in Atlantic bluefin tuna (Thunnus thynnus) larvae reared with copepods in mesocosm system. Aquaculture 426-427, 126-137.

Zaiss, M.M., Papadakis, I.E., Maingot, E., Divanach, P., Mylonas, C.C., 2006. Ontogeny of the digestive tract in shi drum (Umbrina cirrosa L.) reared using the mesocosm larval rearing system. Aquaculture 260, 357-368.

Zambonino-Infante, J.L., Cahu, C.L., 2001. Ontogeny of the gastrointestinal tract of marine fish larvae. Comp. Biochem. Physiol. C 130, 477-487. 